\title{
11. The Liberal Campaign in the 2013 Federal Election
}

\author{
Brian Loughnane
}

On Saturday 7 September 2013 the Liberal and National Coalition won a decisive majority, the Labor Party recorded its lowest primary vote in over 100 years and the Greens had their worst Senate vote in three elections. The Coalition's success was driven by the support of the Australian people for our Plan to build a strong prosperous economy and a safe, secure Australia. It was the result of strong leadership by Tony Abbott, supported by his colleagues, and a clear strategy which was implemented with discipline and professionalism over two terms of parliament.

Under Tony Abbott's leadership, in the past two elections, the Coalition won a net 31 seats from Labor and achieved a 6.2 per cent nationwide two-partypreferred swing. At the 2013 election the Coalition had swings towards it in every state and territory-ranging from 1.1 per cent in the Northern Territory to 9.4 per cent in Tasmania. At the electorate level, the Coalition won a majority of the primary vote in 51 seats. ${ }^{1}$ In contrast, Labor only won seven seats with a majority of the primary vote.

Table 1: Primary vote at 2007 and 2013 federal elections

\begin{tabular}{|l|r|r|r|}
\hline Primary vote & $\mathbf{2 0 0 7}$ & $\mathbf{2 0 1 3}$ & Change \\
\hline Labor & $43.38 \%$ & $33.38 \%$ & $-10.00 \%$ \\
\hline Coalition & $42.09 \%$ & $45.55 \%$ & $+3.46 \%$ \\
\hline Greens & $7.79 \%$ & $8.65 \%$ & $+0.86 \%$ \\
\hline Others & $6.74 \%$ & $12.42 \%$ & $+5.68 \%$ \\
\hline
\end{tabular}

Source: Australian Electoral Commission.

\section{Laying the foundations for victory}

In simple terms, the seats which decided this election were those that did not swing to the Coalition in 2010. We laid the base in 2010 and built on it in 2013. The strategy which drove this momentum was built on a positive plan for Australia's future and an experienced, stable team, led by Tony Abbott, who

1 Includes three-cornered contests where the combined Liberal and National primary vote exceeded 50 per cent. 
emerged over the four years prior to the election as the only true and authentic national leader. It was supplemented by strong local candidates, with good community credentials, who were supported and resourced by the Liberal and National parties.

The foundations for the Coalition's success in 2013 were paradoxically set in our defeat in 2007 and the period immediately afterwards. The party's ability to contain its losses in 2007 provided a strong base on which we could rebuild. This was due to the economic and social achievements and the competence and stability of the Howard Government. The party, although defeated, retained very important and salient strengths in the eyes of the community. This helped minimise our loss in 2007 and ensured we had a strong parliamentary platform on which to rebuild.

Table 2: Number of seats won by Labor and the Coalition at the 2007 and 2013 federal elections

\begin{tabular}{|l|l|l|}
\hline Seats won & 2007 & 2013 \\
\hline Labor & 83 seats & 55 seats \\
\hline Coalition & 65 seats & 90 seats \\
\hline
\end{tabular}

Source: Australian Electoral Commission.

Going into opposition, our expectation was that the new Rudd Government would operate in a manner not dissimilar to the Hawke and Keating governments. It quickly became clear this was not the case and that the Rudd Government was drifting and-as I explained in my National Press Club speech after the 2010 election $^{2}$ - quickly provided political opportunities for the Coalition. Despite the challenges, we achieved a remarkable result at the 2010 election for a first term opposition, resulting in the Coalition winning more seats than Labor, but a hung parliament.

After the 2010 election the Coalition went through the process of discussion with the Greens and independents because we believed securing a stable parliament was in the national interest. However, we did not expect that the crossbench was seriously considering supporting a minority Coalition government, and we were not prepared to concede key values and principles with which the Coalition is closely identified.

2 See also my chapter in Simms and Wanna (2012). 


\section{Labor's politicking}

Labor by contrast appeared willing to pay any price - and ultimately did. This was most obvious in the deal Labor signed with Bob Brown and the Greens. Labor did not need to do that deal and, if the party had any core integrity, it would not have. What would have happened if Labor had refused to enter a formal pact with the Greens? Does anyone seriously believe the Greens would have voted on the floor of the parliament to support an Abbott Coalition government? The deal with the Greens was a sign of Labor's weakness, not of its strength, and it meant the Labor Government was unnecessarily compromised from the start.

The most apparent manifestation of this was in Labor's decision to break its clear commitment to the Australian people not to introduce a carbon tax. Labor did not need to do this because the Greens ultimately would have continued to support them on the floor of the House. But Labor's strategic weakness, coupled with its own internal ideological confusion, resulted in the unnecessary and poorly thought through carbon tax.

Many of the senior Labor figures during this period were clearly more skilled at politics than governing. A hung parliament therefore, at one level, played to their strengths. Julia Gillard was not a strong leader in the sense of having a vision for our country or even a clear policy agenda. But her strength was tactical. She was prime minister because she could command a majority of votes in the Labor caucus and a working majority on the floor of the House. She faced real and significant threats to both majorities. Almost all of the history of the Gillard period can be simply explained by the compromises and deals she needed to make to maintain her position. Her priority was survival today, rather than building a track record of achievement and ultimately a case for reelection. Practically nothing was off the agenda, resulting in policy confusion, significant maladministration and grubby unethical deals. Nothing was ever as it seemed and Australians came to believe they were never getting the full story from Labor.

Our research showed growing community concern at what was happening in Canberra and a sense of drift developing from the lack of leadership that was impacting on business and consumer confidence. Labor was all politics and no policy.

Australians became increasingly concerned at the lack of budget management and in particular the growing debt and deficit. Every few months Labor chopped and changed its approach to these issues and had no credible comprehensive strategy to deal with them. The community knew this and was deeply worried by it. Labor seemed more concerned with the politics of the surplus (or lack thereof) than actually developing a path to achieving one. 
The same was the case with border security. Labor decided immediately after the 2007 election to change the successful Howard Government border security policy. It did so, not because of any policy failure, but because of internal political pressure within Labor. Having made the change it was unable to return to the proven Howard policies and spent the subsequent six years with a series of compromised positions which the people smugglers interpreted as a sign of weakness.

Driving much of this was the unresolved leadership issue within Labor. All Australians knew Labor was a divided camp and that Julia Gillard was a compromised leader. Kevin Rudd was actively making mischief-and everyone knew it. This reached a crescendo when Rudd resigned from cabinet and launched his first direct challenge. The character assessments given by numerous Labor figures about Kevin Rudd, while not surprising Australians, removed any pretence of a united government focused on the concerns of the community. Taken together, Labor's behaviour during the hung parliament created a picture in the public's mind of chaos, instability and dysfunction.

But at the outset of the 43rd parliament the Coalition was not to know just how bad Labor would become. We had to assume they would govern competently with the real possibility of an early election. We therefore spent considerable time after the 2010 election reviewing our situation and from that developed a comprehensive strategy which drove our approach over the subsequent three years. We determined we needed to build community support for our policies and our team, not just wait and assume Labor would fail. This decision became the foundation of our strategy.

\section{The Liberal Party campaign: A positive alternative}

The Coalition retained very strong policy credibility in the public's mind, built on the legacy of the Howard Government and the policies we took to the 2010 election. At a time of policy drift and compromised leadership, the strength and clarity of Tony Abbott and his senior colleagues were a strong foundation for the Coalition to build on.

After the 2010 election, Tony Abbott and the senior leadership team began a major outreach program, travelling to all parts of Australia, listening and assessing our policy direction. A major policy review, conducted by a group chaired by Andrew Robb, produced the detailed, fully-costed policies we took to the election. Tony Abbott himself, in the three years leading up to the 2013 election, conducted over 50 community forums. 
From this process Tony Abbott began making a series of major speeches, expanding on the policy priorities and direction of the Coalition. We published the most important of these speeches at the end of 2012 in a volume titled A Strong Australia (Abbott 2012). The Coalition's policies were practical and addressed directly the key challenges facing Australia. They were designed to drive economic growth in a way which is achievable and affordable.

Political commentary on elections has a tendency to dwell on negative campaigning and consequently often misses significant changes that are occurring. The focus of successful campaigns around the world over the past decade has increasingly been on the positive rather than the negative. To emphasise our positive alternative was a key strategic decision the Coalition leadership took early on in our campaign preparations and it drove much of what we did. But because of the chaos in the Labor Party much of the commentary missed this important development.

A key step in our campaign was the launch at the start of 2013 of our Real Solutions Plan, which set out the Coalition's values, priorities and direction. The book's launch was supplemented by television advertising across Australia in late January 2013 and was an important step in building the Coalition's credibility as an alternative government.

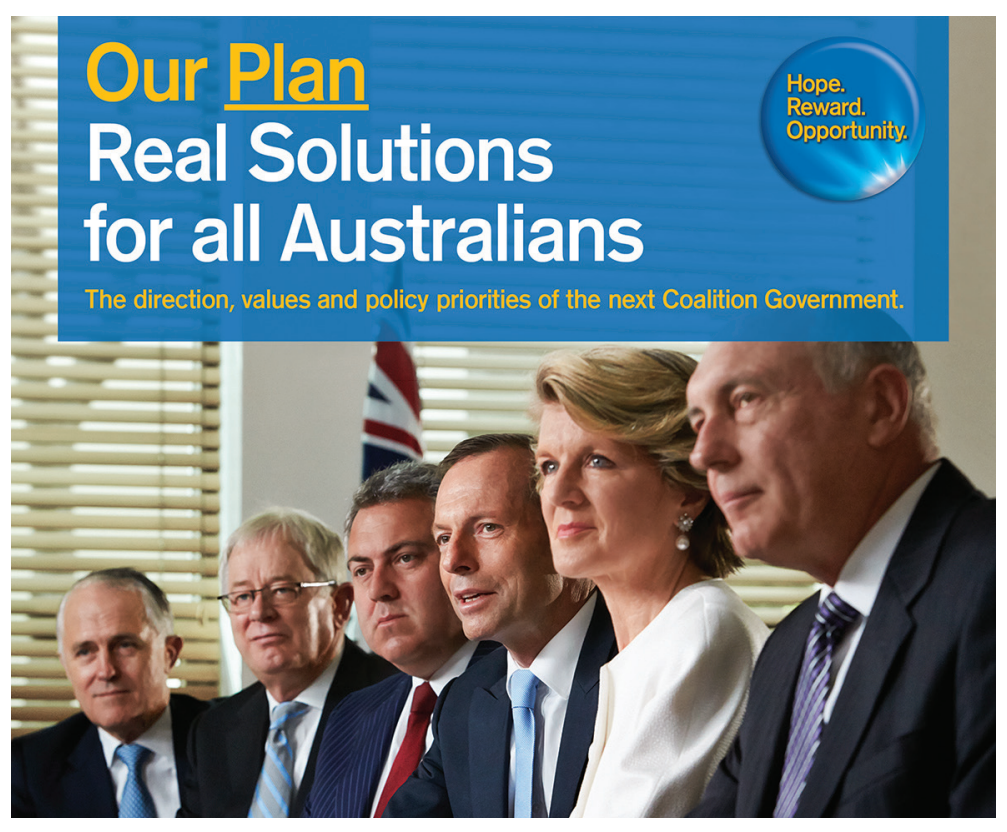

Figure 1: Front cover of Our Plan: Real Solutions for all Australians

Source: Liberal Party of Australia. 
We continued to advertise during the first half of the year, almost entirely on our positive Real Solutions Plan. The Plan was one of the most comprehensive documents ever produced by an opposition and provided a clear policy direction for our MPs, candidates and supporters. In addition, over five million copies of a 16-page condensed version were circulated to households across Australia.

By the start of 2013 the Coalition parties had also preselected candidates in most key seats. The calibre of these candidates was particularly strong and most had been actively campaigning in their local communities for at least 12 months by the time of the election. The swing to the Coalition in the 17 seats gained from Labor on 7 September was over 6 per cent compared to the national swing of 3.6 per cent, confirming the strength of our candidates against popular, entrenched Labor incumbents - an important contribution to our overall success. The party invested significant resources over the three years to the election supporting our candidates with experienced on-the-ground campaigners and improved systems and technology, including social media and micro-targeting.

Table 3: 2013 federal election, House of Representatives-swings to the Coalition in the 17 seats gained from Labor

\begin{tabular}{|l|l|r|r|}
\hline Seat & State & TPP & Swing \\
\hline Banks & NSW & 51.83 & +3.28 \\
\hline Barton & NSW & 50.31 & +7.17 \\
\hline Bass & Tas & 54.04 & +10.78 \\
\hline Braddon & Tas & 52.56 & +10.04 \\
\hline Capricornia & Qld & 50.77 & +4.45 \\
\hline Corangamite & Vic & 53.94 & +4.22 \\
\hline Deakin & Vic & 53.18 & +3.78 \\
\hline Dobell & NSW & 50.68 & +5.75 \\
\hline Eden-Monaro & NSW & 50.61 & +4.85 \\
\hline Hindmarsh & SA & 51.89 & +7.97 \\
\hline La Trobe & Vic & 54.01 & +5.67 \\
\hline Lindsay & NSW & 52.99 & +4.11 \\
\hline Lyons & Tas & 51.22 & +13.51 \\
\hline Page & NSW & 52.52 & +6.71 \\
\hline Petrie & Qld & 50.53 & +3.04 \\
\hline Reid & NSW & 50.85 & +3.53 \\
\hline Robertson & NSW & 53.00 & +4.00 \\
\hline Average & & & +6.05 \\
\hline
\end{tabular}

Source: Australian Electoral Commission. 
A critical step in building our positive alternative was Tony Abbott's 2013 Budget-In-Reply speech. It set out a clear positive alternative to Labor and was an important moment in the community accepting him as an alternative prime minister, rather than simply leader of the Opposition.

\section{Our response to Labor's leadership change}

As part of our campaign planning, we had assumed that Julia Gillard might be replaced as Labor leader, most likely by Kevin Rudd, and possibly at short notice. We were, however, conscious of the reluctance of Labor to return to Rudd and had also prepared in the event somebody else became Labor leader.

We were therefore ready when Kevin Rudd returned. We quickly made the critical decision not to significantly alter our strategy. In my view, leadership was just one element of the serious problems responsible for Labor's weakened position. We thought a change of leader might result in a short bounce of support, but unless Labor addressed their underlying challenges, nothing would change fundamentally. We were conscious of Kevin Rudd's skill as a message manipulator and closely monitored developments and calibrated our strategy accordingly. Nevertheless, at no stage did we move from our emphasis on presenting a clear, strong and credible positive alternative. By the start of the formal campaign we were confident our strategic settings were correct and that Kevin Rudd's return had not changed the fundamentals of the election.

Put simply, Labor's change to Rudd in the lead up to the election did not work. In our private polling Rudd declined quickly, ending with a worse 'net favourability' and 'preferred prime minister rating' than Julia Gillard before the change. By the start of the campaign Rudd's lead over Tony Abbott as preferred prime minister was neutralised and he never regained the lead. This, in my view, helped explain why Labor retreated to such a negative, defensive campaign as it became more desperate.

\section{Other strategic elements of the campaign}

The campaign was important in determining the final result. As in every election, a contest can be won or lost during the campaign period. Tony Abbott and his senior colleagues began the campaign with a series of positive initiatives directly relevant to ordinary Australians. This allowed us to maintain and build on the momentum we had developed before the campaign. Australians were embarrassed by Labor's chaos and were looking closely at the Coalition. The focus of the Coalition's campaign was therefore almost entirely on our positive 
Plan to improve our country. More than 70 per cent of our advertising was based on this positive alternative. Australians did not want to vote against a bad government. They wanted to embrace and support a positive alternative which would make a real difference to their lives. Figures 2 and 3 indicate this message.

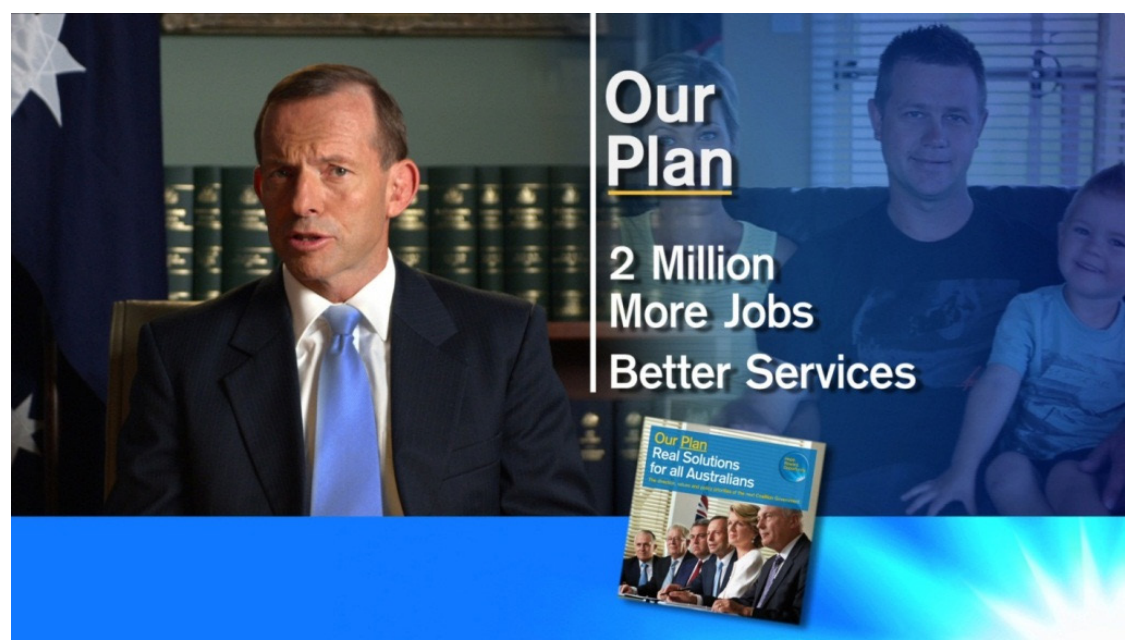

\section{Figure 2: Liberal television advertisement promoting Our Plan}

Source: Liberal Party of Australia.

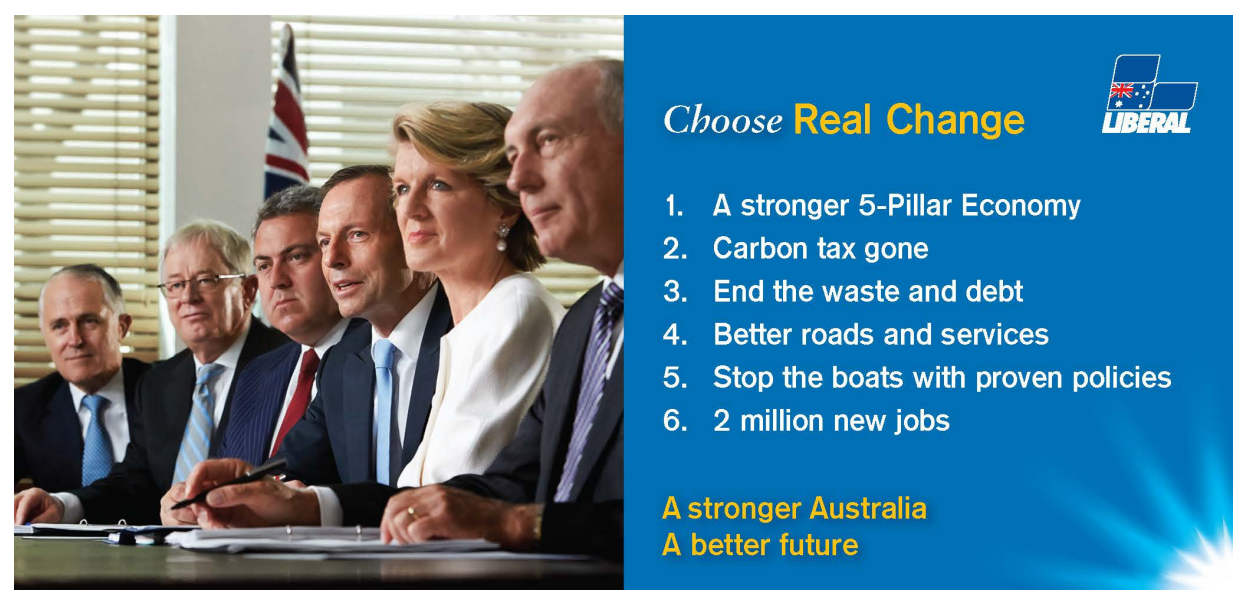

Figure 3: Back page of Liberal Party how-to-vote cards

Source: Liberal Party of Australia.

For most of the last term of Parliament, Labor attempted to make something of the costings of Coalition policies. We determined early on to have a comprehensive detailed process run by respected independent experts. We were confident our 
modest policy announcements and savings were affordable and in line with our commitments to responsible budget management. Once again Labor's addiction to politics, rather than sensible policy and analysis, led them to overplay their hand. At no point during the last parliament was there any credibility to Labor's claims. Joe Hockey and Andrew Robb oversaw a rigorous, detailed process that gave us great confidence in the viability of the policies we announced. The Coalition's costings process set a new standard for opposition and, given Labor's emphasis on its importance, the Australian people expect Labor in opposition to at least match the exacting standard for costings set by us. The costings process, and Labor's failed attacks on it during the campaign, further strengthened the Coalition as a credible alternative in the minds of the public and great credit goes to Joe Hockey for the important responsibility he shouldered during the campaign.

The Coalition team was a vital element of our campaign over the past three years. Labor was clearly split and most of its best people were refusing to serve. The stability of our shadow ministry for the whole of the last term contrasted dramatically with the revolving door of Labor ministers in key portfolios and was an important factor in our success.

Our research confirmed our policy positions were much more closely aligned to the concerns of the community than Labor's. Economic management, broadly defined - including taxes, debt, the deficit, jobs and cost of living for families was by far the most significant issue. Border security and immigration was also an issue of significance. Our post-election research confirmed issues and policies were more important than ever. Issues were a primary focus for 36 per cent of the electorate in this election, an increase of 8 per cent on the 2010 election in the key seats.

The Liberal brand is significantly stronger than either Labor or the Greens and has strengthened over the past five years. According to our research we were seen to 'run a strong campaign with a clear message', and to have a large lead over Labor on 'positive plans and goals for the future'. Not surprisingly, we also had a very strong lead on the important indicator of being able to 'provide strong, stable government after the election'.

\section{Conclusion}

So in summary, while Labor's internal crisis provided opportunity for the Coalition, it was not inevitable that we would win the election. The community wanted something to vote for not just against. The Coalition's positive Real 
Solutions Plan, strong leadership, united team and outstanding candidates, together with a clear strategy that was followed throughout the last term with great discipline, drew strong community support.

It is why the Coalition won the election rather than Labor lost it.

\section{Appendix}

\section{Federal election 2013: key facts}

- The average two-party-preferred swing in the 17 seats that the Coalition won from Labor was over 6 per cent-close to double the national average (3.6 per cent).

- The Coalition has won more seats than Labor in six of the last seven federal elections (1996, 1998, 2001, 2004, 2010 and 2013).

- In 2013, Labor received its lowest primary vote since 1903 (lowest in over 100 years).

- Labor has had a swing against it in four of the five last federal elections (2001, 2004, 2010 and 2013).

- Labor's primary vote under Rudd in 2013 was 10 per cent lower than it was under Rudd in 2007.

- The Coalition received 1,571,453 more primary votes than Labor (Coalition: 5,882,881 vs Labor: 4,311,365).

- The Coalition won 51 seats with a majority of the primary vote; Labor only won seven seats with the majority of the primary vote.

- Labor received its worst Senate result since the Senate was expanded in 1984.

- The Greens Senate vote of 8.6 per cent is the lowest since 2004 (7.7 per cent in 2004); their vote halved in Tasmania (16.8 per cent in 2010 vs 8.3 per cent in 2013).

- The Coalition has achieved more than 50 per cent of the two-party-preferred in four of the last seven elections, but has won more seats than Labor in six of the last seven elections.

- During the campaign, the Liberal Party website had 980,000 unique visitors, compared to 556,000 unique visitors to the ALP website.

- On the Friday before polling day, the Liberal website had 106,000 unique visitors compared to just 56,000 unique visitors to the Labor website.

- Tony Abbott's Facebook page 'likes' grew during the campaign by over 550 per cent, to achieve 258,830 'likes' compared to Kevin Rudd's 127,476 'likes'. 
- The Liberal Party's Facebook page had more than 200,000 'likes', compared to just 165,000 for Labor.

- The engagement rate for Tony Abbott's Facebook page was three times that of Kevin Rudd's page.

- During the campaign, the Liberal Party released the first 'targeted sharing' app ever developed in Australia, which used Facebook data to personalise a video - and then ask that person to ask their friends to vote for the Coalition. This targeted sharing app reached 7.5 million Australians on Facebook.

- The number of Tony Abbott's Twitter followers grew by 28 per cent compared to one per cent for Kevin Rudd during the campaign.

- The Liberal Party's YouTube channel received 1.2 million views during the election compared to less than 300,000 for the ALP channel.

- The most popular video on the Liberal Party channel has received over 432,000 views compared to Labor's most watched video with 109,000 views.

\section{References}

Abbott, Tony. 2012. A Strong Australia: The values, directions and policy priorities of the next Coalition government. Canberra: Liberal Party of Australia. Available online from the website of the Liberal Party of Australia, viewed 18 March 2014: <shared.liberal.org.au/Share/eBooks/StrongAustralia.pdf>.

Abbott, Tony. 2013. 'Budget Reply'. Parliament House, Canberra, 16 May. Transcript available online from the website of the Liberal Party of Australia, 16 May, viewed 18 March 2014: <www.liberal.org.au/latestnews/2013/05/16/tony-abbott-budget-reply-parliament-house-canberra $>$.

Liberal Party of Australia. 2013. Real Solutions for all Australians. Canberra: Liberal Party of Australia. Available online from the website of the Liberal Party of Australia, viewed 18 March 2014: <lpa.webcontent.s3.amazonaws. com/realsolutions/LPA\%20Policy\%20Booklet\%20210x210_pages.pdf>.

Loughnane, Brian. 2010. 'Address to the National Press Club'. Canberra, 10 November. Transcript available at Australianpolitics.com, 'Brian Loughnane analyses Result of 2010 Federal Election', 10 November, viewed 18 March 2014: <australianpolitics.com/2010/11/10/brian-loughnane-national-pressclub-address.html $>$.

Loughnane, Brian. 2012. 'The 2010 Federal Election: The Liberal Party'. In Marian Simms and John Wanna (eds), Julia 2010: The caretaker election. Canberra: ANU E-Press. 
This text taken from Abbott's Gambit: The 2013 Australian Federal Election, edited by Carol Johnson and John Wanna, published 2015 by ANU Press, The Australian National University, Canberra, Australia. 